\title{
An Analysis of Needs of Students Disliked by Their Friends Using McClelland's Theory of Needs
}

\author{
Tiara Erganila*, Suwarjo \\ Guidance and Counseling, Graduate Program Pascasarjana, Universitas Negeri Yogyakarta, Yogyakarta, Indonesia
}

Received August 12, 2020; Revised November 13, 2020; Accepted November 29, 2020

\section{Cite This Paper in the following Citation Styles}

(a): [1] Tiara Erganila, Suwarjo , "An Analysis of Needs of Students Disliked by Their Friends Using McClelland's Theory of Needs," Universal Journal of Educational Research, Vol. 8, No. 12A, pp. 7818-7824, 2020. DOI: 10.13189/ujer.2020.082570.

(b): Tiara Erganila, Suwarjo (2020). An Analysis of Needs of Students Disliked by Their Friends Using McClelland's Theory of Needs. Universal Journal of Educational Research, 8(12A), 7818-7824. DOI: 10.13189/ujer.2020.082570.

Copyright $\mathrm{C} 2020$ by authors, all rights reserved. Authors agree that this article remains permanently open access under the terms of the Creative Commons Attribution License 4.0 International License

\begin{abstract}
This study aimed to determine the needs of "AD" as a student who is disliked by his friends in the class by using the McClelland's theory of needs at the State Senior High School of 8 Yogyakarta. This research uses the qualitative approach to analyze "AD" needs according to McClelland's theory of needs. The method of the research is how the solution will be informed according to the recent data. The subject was obtained through sociogram results from sociometry in class X Social Sciences 1 . There are some steps in this research. First, draw the hypothesis based on the field data. Second, search and determine the informations required through interviews, observations and instruments in the form of rating scale. Furthermore, the needs of "AD" are compiled using the rating scale and analyzed using McClelland's theory of needs. Then, there are 20 indicators of needs that can prove "AD" is a disliked student. According to McClelland theory of needs, there are three needs that "AD" craved for: Needs for Affiliation $72 \%$, Needs for Achievement 68\%, Needs for Power $48 \%$. Based on the results of the study on the analysis of needs of students disliked by their friends using McClelland's theory of needs at the State Senior High School of 8 Yogyakarta, it can be concluded that "AD" is the most disliked student. The main cause is the bad label of "AD" so that there is a gap between "AD" and his group who is his own classmate.
\end{abstract}

Keywords McClelland's Theory of Needs, Student Needs Analysis, Students Disliked by Their Friends

\section{Introduction}

The school has a very important meaning for the life and development of students. Schools are considered to be able to meet some of the needs of students and determine the quality of their life in the future [1]. According to [2], schools in Indonesia consist of several levels of education in general, including Early Childhood Education (PAUD), Elementary School (SD), Junior High School (SMP), Senior High School (SMA), and College. If determining the starting point of adolescence is quite difficult, determining the ending point is even more difficult because "adolescence" in a wider sense is much more outreach than puberty. The term adolescence is derived from the word adolescere which means growing towards maturity[3]. Because most boys mature more slowly than girls [4], boys experience a shorter period of early adolescence, even though at the age of eighteen they are considered adults, as for the girls. As a result, boys often appear less mature for their age than girls [5]. Therefore, Senior High School students in Indonesia are included in the category of adolescence and have developmental tasks. The adolescence developmental tasks [6] include: 1) Accepting physical conditions and using them effectively, 2) Accepting the social role of sex as male/female, 3) Desiring and achieving socially responsible social behaviour, 4) Achieving emotional independence from parents and other adults, 5) Learning to get along with groups of girls and boys, 6) Development of value scales, 7) Consciously developing a closer overview of the world, 8) Preparation to be economically independent, 9) Job 
selection and training, 10) Preparation for marriage and family. From the developmental tasks above, points 4,5,7 are related to developmental tasks from the social and personal aspects of adolescents. Based on the findings in the field at the State Senior High School of 8 Yogyakarta, which is one of the leading Senior High Schools in Yogyakarta, the researchers distributed questionnaires of sociometry to seven classes of grade X (Natural Sciences and Social Sciences) and four classes of grade XI (Natural Sciences and Social Sciences). The results obtained several names of students who were disliked by their friends. Once the results of sociometry were obtained, the researchers chose class X Social Sciences 1 as the research subject, in which the class hasone most disliked student, given an initial "AD", in which almost all of his friends chose him as a disliked student with a total of 26 of 31 students in that class. "AD" is a student with a bad label at the school. In this study, the researchers chose McClelland's theory of needs as the basic theory of needs because it is considered to have a broader scope and covers human needs as a whole. McClelland's theory of needs is widely used in economic research, but is also used in the field of education because there are three aspects that are included as human needs based on this theory in general, consisting of affiliation, power, and achievement [7]. In several previous educational studies, McClelland's theory of needs was used to measure individual motivation. This study is limited to one of the functions of Guidance and Counseling, which is the function of understanding. If this study is not conducted, the treatment provided is less effective due to a lack of in-depth understanding of the needs of students disliked by their friends. Based on the explanation of the background above, the researchers will conduct research on the needs of students disliked by their friends by using McClelland's theory of needs at the State Senior High School of 8 Yogyakarta. This study is important to help "AD" achieve his developmental tasks optimally.

\section{Materials and Methods}

Based on the type of data, the research approach used in this study was a qualitative descriptive approach. The method used was by trying to reveal the current problem solving based on the data. This type of qualitative descriptive research used in this study was intended to obtain information about the needs of "AD" as a student disliked by his friends by using the McClelland's theory of needs at the State Senior High School of 8 Yogyakarta comprehensively. In addition, with a qualitative approach, it is expected that the situation and problems of the needs of "AD" as a student disliked by his friends in the class can be determined. The subject was obtained through sociogram results from sociometry in class $\mathrm{X}$ Social
Sciences 1. Descriptive research, based on its characteristics, has certain steps in its implementation. According to [8], these steps are as follows:

\section{a). Formulating Research Problems}

Any research method must begin with a problem, which is the submission of research questions whose answers must be sought using data from the field. The research problem contains variables that are studied in this study. In descriptive research, researchers can determine the status of the variables or study the relationship between variables. The formulation of the problem of this study is what the needs of "AD" based on McClelland's theory of needs.

\section{b). Determining the type of information required}

In this case, the researchers need to determine the information needed to answer the questions or problems that have been formulated. Qualitative information is related to data or information in written form in the form of sentences and paragraphs. The data in the field are in the form of matters related to the needs of "AD" based on McClelland's theory of needs.

\section{c). Determining data collection procedures}

There are two elements of research needed, including the instruments or means of collecting data and the source of the data or sample, which is where the information should be obtained. In a study, there are data collection tools, including interviews, observations, psychological scales, and sociometry. To obtain a clear sample, the research problem must be formulated as specifically as possible so that it provides a definite direction for the instruments and data sources. In this study, the data were obtained using interviews, observations, and an instruments in the form of a rating scale to measure student needs based on McClelland's theory of needs.

\section{d). Determining information or data processing procedures}

Data and informations that have been obtained with the selected instruments and certain data sources are still rough information or data. This information and data need to be processed so that it can be used as a material to answer research questions. The results of the data in this study were collected to obtain valid information as research data.

\section{e). Drawing research conclusions}

Based on the results of data processing above, the researchers conclude the results of descriptive research by answering research questions and synthesizing all these answers in one conclusion that summarizes the overall research problem. 


\section{Discussion}

To determine the needs of "AD" using McClelland's theory of needs, the data were collected through a rating scale and based on the analysis, it obtained the needs by using20 indicators. In this study, it is the needs of "AD" as a student disliked by his friends. Of the three existing needs, it obtained the needs of "AD" by using McClelland's theory of needs, in which Need for Affiliation was $72 \%$, Need for Achievement was $68 \%$, and Need for Power was $48 \%$.

The need for affiliation is the most important with an average scale of always important. According to "AD", friendship gives impacts on his daily life even though "AD" knows that he is less accepted by his group. Friendship is not only about being liked, but also about giving, appreciating, and helping each other [9]. "AD" has long been considered a bad student since he was in Junior High School. "AD" also admits that he experienced high emotional outbursts in his early adolescence. "AD" is left by most of his friends and now "AD" realizes that friendship is important for motivation, fun life and school when "AD" feels genuine friendships in his adolescence.

The second highest need is an achievement. The low social position makes "AD" have a high motivation to have achievement and be recognized by his group. The need for achievement of "AD" is important because with the achievement of "AD", it is believed that "AD" is starting to be accepted and not experiencing a social situation as he faced so far. Process, learning, and challenges remain a quite high need for "AD" to develop himself. This is also proves that others' opinion is wrong. "AD" admits that he turned aggressive in his adolescence but that did not turn him into a useless person. "AD" knows his potential, even though "AD" is not good at academics and continues to be underestimated, "AD" is able to try and compete in order to be accepted and liked by his friends because he has good potential in the fields of skills and sports.

The need for power of "AD" is on the scale of moderate and tends to be low. "AD" considers himself as inferior in the class because of his unfavourable circle of friends so that "AD" must follow the wishes of the class without being able to impose his will or at least be listened to in expressing opinions to solve problems together. The need for power will also increase when the existence of "AD" begins to be recognized and accepted in the class. "AD" withdraws himself so that he considers power is not for him who has few friends. The decision of "AD" to back off is also influenced by friends who do not like him so that "AD" considers backing off as the best decision to improve himself. However, "AD" does not close himself from students who want to be friends with him because his greatest need is friendship.

Based on the above discussion, it is known the needs of "AD" by using McClelland's theory of needs, including the affiliation, achievement, and power. Thus, it can be concluded that the needs of the student that is disliked by their classmates due to being labelled as bad in the past is the motivation of friendship so that they are accepted by their group. According to WHO, adolescents are defined as more conceptual. In this definition, three criteria are stated, consisting of biological, psychological and socio-economic aspects [10]. The needs of "AD" using McClelland's theory of needs are needs from a psychological aspect as an adolescent. Biologically and socio-economically, the needs of "AD" are also known by analysing using McClelland's theory because, besides psychological aspect, biological and socio-economic aspects also influence individual needs [11], in this study, "AD". For friendship, it will biologically affect the hormones in the body because feelings of happiness will give positive energy compared to when "AD" feels alone and disliked by his friends in class. In socio-economic aspects, adolescents tend to be more economically independent. Nowadays, adolescents generally spend more time outside the house to go to cafes for gathering with their friends. This costs money because a person's social status also affects the cycle of friends. In this case, since "AD" really needs friendship, "AD" also needs costs to carry out friendships in the school environment and to be well-accepted. However, it is quite difficult because the bad label he has is still strongly attached to him.

Regarding the adolescence developmental tasks that must be achieved optimally by "AD", he has tried to do the best he can. "AD" makes efforts so that he can optimally achieve the adolescence developmental tasks, which according to [12] are to achieve new and more mature relationships with peers, both male and female, achieve emotional independence from parents and other adults and obtain a set of values and ethical system as a guideline to behave to develop ideology. Although "AD" is depressed because he is disliked by his classmates, "AD" begins to realize that changing bad attitudes into good ones is one of the real actions that "AD" must take so that the adolescence developmental tasks are accomplished and "AD" is accepted so that he is liked by his friends or at least not being the most disliked student in his class.

There are two matters that become problems, including personal problems and typical problems of adolescents. According to [13], these problems arise because the adolescent development tasks are not achieved or are not optimally achieved. Adolescents usually exaggerate minor problems and create problems that do not exist. Naturally, this problem will be faced by adolescents, but adolescents who are able to control themselves and think well will not be bothered by problems [14]. The needs of "AD" according to McClelland's theory of needs, adolescence developmental tasks, and the obstacles have been identified in this study. After collecting data in the form of relationships in a group, it obtained that "AD" becomes the student who is in the outermost circle. The relationships of "AD" and his friends are centralized 
social relationships with high popularity within the group, but negative in nature. Basically, "AD" does not really know his classmates because when the questionnaire of sociometry was collected, it was in the first semester of class $\mathrm{X}$ when the students just entered the school for several months. However, "AD" had been known to have bad behaviour during Junior High School, so that his classmates considered it more than to start to know "AD" well in class. This is what makes "AD" unwelcome in the class. Besides, "AD" also tended to be aggressive at the beginning of school because he had received underachievement in his class. "AD" often got angry and refused group activities. However, in the second semester, "AD" began to change and accept the situation and tried to get his bad label off. The purpose of conducting sociometry in the class is not to declare that "AD" is disliked by his friends, but to find out the form of relationships that exist in the class and to help "AD" as a student who is selected as a disliked student by his friends to change the form of a bad relationship for the better.
The needs of isolated students in this study are reviewed from McClelland's theory of needs, which states that there are three important needs that can build motivation. These three needs include: 1) need for power, 2) need for affiliation, and 3) need for achievement. According to[15], to obtain the proper data, it is necessary to determine informants who are competent and in accordance with data needs (purposive). The subjects were obtained through sociogram results from sociometry in class X Social Sciences 1. Based on the sociogram, it obtained that "AD" is in the farthest position from the friendship circle. In this sociometry, there are two questions, including:

1) Mention three friends that you like the most in the class.

2) Mention three friends that you dislike the most in the class.

From these questions, one name emerged with a total of 26 students of 31 students in the class placing "AD" as the unpopular and most disliked student.

\section{Results}

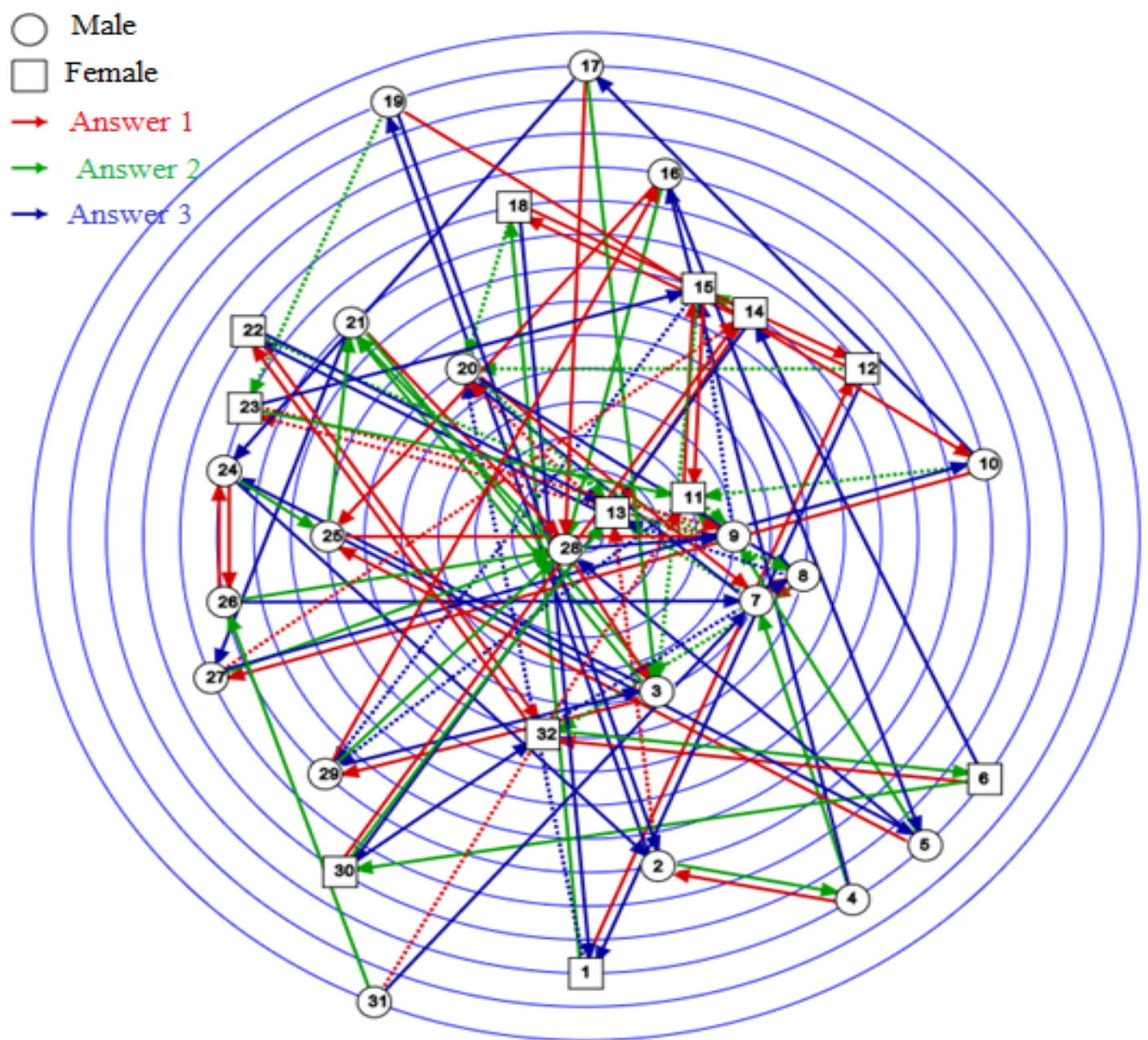

Figure 1. Sociometric results 
Table 1. The instruments of McClelland's Theory of needs

\begin{tabular}{|c|c|c|c|c|c|}
\hline \multirow{2}{*}{ No. } & \multirow{2}{*}{ Variable } & \multirow{2}{*}{ Indicator } & \multicolumn{2}{|c|}{ Item Number } & \multirow{2}{*}{ Total } \\
\hline & & & Favorable $(+)$ & Unfavorable (-) & \\
\hline 1 & \multirow{3}{*}{$\begin{array}{l}\text { The needs of } \\
\text { isolated } \\
\text { students }\end{array}$} & Need for Power & $1,2,5,8,10$ & $3,4,6,7,9$ & 10 \\
\hline 2 & & Need for Affiliation & $11,12,15$ & 13,14 & 5 \\
\hline 3 & & Need for Achievement & 16,20 & $17,18,19$ & 5 \\
\hline \multicolumn{5}{|c|}{ Total } & 20 \\
\hline
\end{tabular}

The sociometry above is divided into two respondents, boys are shaped in circle while girls are shaped in square. Every students chose 3 most popular students, marked by red arrow as the first pick, green arrow as the second pick, and blue arrow as the third pick. The popular students will be in the middle of the sociometry circle, while the unpopular one will be further away in the outer circle of sociometry. The results of the sociometry showed that "AD" is the last pick (31st pick) and in the outer circle, so that "AD" is the most unpopular and disliked student.

Furthermore, data were collected regarding the needs of "AD" by using a rating scale to determine the whole needs of "AD". Based on the data collection techniques used, this research instruments used interview guidelines, documentation, and observation, while to measure the needs of "AD" based on the McClelland's theory of needs, it used a rating scale. The following Table 1 are the instruments.

In this study, the data obtained were in the form of qualitative descriptive data, which is the need for "AD" based on McClelland's theory of needs. The qualitative data analysis used in this study is inductive, which is an analysis based on the data obtained, then a certain relationship pattern is developed or becomes a hypothesis[16]. Thereby, data analysis techniques can be interpreted as a way to carry out data analysis, with the aim of processing the data into information, so that the characteristics or properties of the data can be easily understood and useful for answering problems related to research activities, whether related to data descriptions or to make inductions, or draw conclusions about population (parameters) characteristics based on data obtained from samples (statistics).

In collecting data about the needs of "AD", the Rating Scale instruments was given to the subject by direct interview. "AD" was given the opportunity to answer twenty statements using a Likert scale along with the reasons for each statement. According to [17], the statement with the answer Always (A) is equivalent to the score of 5 , Often $(\mathrm{O})$ is equivalent to the score of 4 , Sometimes (S) is equivalent to the score of 3, Rarely (R) is equivalent to the score of 2 , and $\operatorname{Never}(\mathrm{N})$ is equivalent to the score of 1 . The twenty statements were based on indicators of needs according to McClelland's theory. There were ten statements to determine Needs for Power, five statements for Needs for Affiliation, and five statements for Needs for Achievement. With this number of statements, it is known that the highest score on the Rating Scale is 5 times 20 or 100 . Besides the scale, "AD" also described the reasons for each answer "AD" gave during the interview. The needs of "AD" are:

\section{Need for Power}

According to McClelland, the need for power consists of 10 indicators. In this study, the researchers used a rating scale to determine the scale of the need for power of "AD". Each statement will be converted into a score, presented, and re-elaborated based on the reason of each statement conveyed by "AD". "AD" expressed that he feels he sometimes gives no impacts in the classroom (3). This is because when he is needed, "AD" is considered important. "AD" also sometimes prioritizes the needs of the class because "AD" feels that when he has duties, becoming a helper, and helping urgent matters, he is placed as a priority (3). After that, "AD" feels ignored. "AD" feels that he is rarely considered important in class (2) However, "AD" never considered his classmates as insignificant and had no effect (1). Even though friends in his class often behave badly, only considering him when they need him, but for "AD", friends are still important. In facing problems in class, "AD" never gave an opinion because "AD" felt that he would not be heard (1). Due to his limited friends, "AD" never treated his friends as "subordinates" (1). However, "AD" still insists on being followed by his friends even though he is ignored. To listen to other people, "AD" always feels a need, but only for his closest friends whom he thinks always becoming reminders (5). Advice from friends that are considered true by "AD" will be followed by him, but those that are wrong according to him will be ignored (5). "AD" also feels that he is not important, so if his opinion is not heard by others, he cannot constrain them but still wants his opinion to be carried out (1). In following opinion suggested by others, "AD" rarely does it because he will only do it when his friends urge him to do something his friends cannot do (2). Of the ten statements answered by "AD" along with the reasons, it is known that the score obtained by "AD" is $(3+3+2+1+1+1+5+5+1+2)$ or 24 , out of the highest score of 50 (5 (highest score) $\times 10$ (number of statements)), which can be simplified as $24 / 50=48 \%$. Based on the results of the Rating Scale, the needs of "AD" as a student who is disliked by his friends in school 
reaches $48 \%$.

\section{Need for Affiliation}

Friendship is a need for all humans. In this case, "AD" as an isolated student also has the same need. Yet, the scale is different between one to another, including for "AD". In the need for friendship, there are five statements provided by "AD" to answer along with the reasons. Social relations and greetings with the surrounding favoured by "AD" in frequent intensity. According to "AD", because "AD" also needs other people and vice versa, he tries to build relationships with his friends on a frequent scale (4). Meanwhile, considering that friends are valuable and "AD" feels that he has them and cares about them is only on an occasional scale (3). This is because "AD" feels that his meetings with school friends are limited at the school only. Outside school, "AD" is busy playing with friends at home and rarely has activities with friends from school after school hours. In friendship at school, "AD" feels that he only has few friends and "AD" wants to have more friends. However, "AD" does not insist even though only a few who want to be friends with him. "AD" admits that he rarely feels disappointed when he acknowledges that he only has few friends. For "AD", his current friends are more than enough as long as the relationship is maintained (2). In line with the above statement, "AD" states that he always likes friends who understand him and vice versa (4). For him, reciprocity is very important. "AD" also always likes friendship and helping others (5). In terms of helping others in the lesson, "AD" admits that he is not able. But, for other matters, "AD" will try his best for his friends. From five statements, it is known that the score obtained by "AD" is $18(4+3+2+4+5)$ out of 25 (5 (highest score) x 5 (number of statements)), so that the score of "AD" in this need category is $18 / 25$ or $72 \%$. This need is a high need, considering the position of "AD" in the class as a student disliked by his friends. It turns out that the need to open up and make friends is very high and is the highest need.

\section{Need for Achievement}

The need for achievement or appreciation is one of the human needs according to McClelland. In his interest, "AD" mentions swimming is interesting for him. Further, "AD" admits that he always wants to make achievements in this field but he does not expect any awards or medals (1). For "AD", the greatest reward is satisfaction. If in his interest, "AD" experiences failure or defeat, "AD" sometimes feels discouraged (3). However, this does not last long, sometimes even being ignored by "AD". "AD" also often does things that are considered reasonable but is still willing to take risks when doing something (4). The success or failure must be accepted. For work results, "AD" always prioritizes the process (5). The results are a bonus for the effort. Besides, "AD" always considers motivation as satisfaction, independence, and progress to succeed (5). "AD" considers the motivation of the people around him as his strength, but these people are those who are considered important for his life. From the statements answered by "AD", it is known that the score of "AD" for the need for achievement is $17 / 25$ or $68 \%$, which is considered as the high need for "AD". This is certainly related to his position as a student disliked by his friends in the class. Once "AD" succeeds in his interest, "AD" believes that his presence will start to increase and he will be liked by his classmates more.

\section{Conclusions}

Based on the results of the study on the analysis of needs of students disliked by their friends using McClelland's theory of needs at the State Senior High School of 8 Yogyakarta, it can be concluded that "AD" is the most disliked student. The main cause is the bad label of "AD" so that there is a gap between "AD" and his group who is his own classmate. Meanwhile, the needs of "AD" based on McClelland's theory of needs show that the highest needs of "AD" as a student disliked by his friends are affiliation, achievement, and power. This is closely related to the social position of "AD" in the class which forms the level of "AD" needs analyzed using McClelland's theory of needs.

\section{Acknowledgments}

I thank all colleagues and lecturers who have supported the writing of this research article, also thanks to "AD", a student of the State Senior High School 8 Yogyakarta who is to become the subject of this research.

\section{REFERENCES}

[1] Desmita..Developmental Psychology of Students. Bandung: Rosda Karya. 2012.

[2] Yusuf, S. Psychology Children \& Adolescent Development. Bandung: PT. Remaja Rosdakarya. 2011.

[3] Sarwono Sarlito W. Adolescent Psychology Revised Edition. Jakarta: Rajawali Pers. 2012.

[4] Lilly, J, D., Duffy, J.A., Virick, M . "A gender-sensitive study of McClelland's needs, stress, and turnover intent with work-family conflict". Journal of education.Vol. 21 Iss: 8, pp. 662-680. DOI : 10.1108/09649420610712045. 2006.

[5] Hurlock, Elizabeth B. Developmental Psychology (An Approach Along the Life-span of Fifth Edition). Jakarta: Erlangga. 2011

[6] Santrock, J. W. Life-span development: Perkembangan masa hidup. East Jakarta: Erlangga. 2012.

[7] Moberg, C.R., Leasher, M. "Examining the differences in 
salesperson motivation among different cultures", American Journal of Business. Vol. 26 Iss: 2, pp.145-160. DOI: 10.1108/19355181111174525. 2011.

[8] Moleong, Lexy J. Qualitative Research Methodology. Bandung: PT Remaja Rosdakarya. 2017.

[9] Ahmadi, Abu. Developmental psychology. Jakarta; RinekaCipta. 2019.

[10] Muangman. D. Adollescent Fertility Study in Thailand. ICCARP Search. 1980.

[11] Winkel, WS. Psychology of Teaching. Jakarta: Gramedia. 2019.

[12] Gunarsa, Singgih, D. Psychology of Children and Adolescents. Jakarta: Gunung Mulia. 2019.
[13] Batubara, J. “Adolescent Development (Perkembangan Remaja)". Vol 12, No 1, 21-29. 2010.

[14] Alwisol. Psychology of personality. Malang; UMM Press. 2013.

[15] Azwar, Sarifudin. Reliability and Validity. Yogyakarta: Pustaka Pelajar.2019.

[16] Sugiyono. Understanding Qualitative Research. Bandung: Alfabeta. 2012.

[17] Morissan. Survey Research Methods. Jakarta: Kencana Prenada Media Group. 2012. 